\title{
Debt to Equity Ratio, Pertumbuhan Laba, Pertumbuhan Assets dan Return Saham Perusahaan Property dan Real Estate di Bursa Efek Indonesia
}

\author{
Amor Marundha ${ }^{1}$, Widarto Racbini ${ }^{2}$ \\ ${ }^{1.2}$ Universitas Pancasila, Jl. Srengseng Sawah, Jagakarsa, Jakarta Selatan 12640
}

I N F O A R T I K E L

JEL Classification:

G14

Keywords:

debt to equity ratio,

earning growth,

assets growth,

stock return

\begin{abstract}
A $B$ S T R A C T
Masterplan Percepatan dan Perluasan Pembangunan Ekonomi Indonesia (MP3EI) in the long run result in great hopes on the real estate and property sectors. This sector has the potential to continue to grow with regard to the government's efforts to accelerate infrastructure development in Indonesia. This study aims to prove the effect of debt to equity ratio, earnings growth and the growth of assets on stock returns of real estate companies and property. Samples were analyzed for 50 years of data of real estate companies and property. Research results prove that there are significant earnings growth and asset growth on stock returns. The results shows that existence of the debt to equity ratio not significanly affected stock returns.
\end{abstract}

\section{A B S T R A K}

Rencana program Masterplan Percepatan dan Perluasan Pembangunan Ekonomi Indonesia (MP3EI) dalam jangka panjang berakibat pada harapan besar pada sektor real estate dan property. Sektor ini berpotensi terus tumbuh berkaitan dengan upaya pemerintah yang mempercepat pembangunan infrastruktur di Indonesia. Penelitian ini bertujuan untuk membuktikan pengaruh debt to equity ratio, pertumbuhan laba dan pertumbuhan assets terhadap return saham perusahaan real estate dan property. Sampel yang dianalisis sejumlah 50 data tahun perusahaan real estate dan property. Hasil penelitian membuktikan bahwa terdapat pengaruh pertumbuhan laba dan pertumbuhan asset terhadap return saham. Hasil penelitian tidak berhasil membuktikan adanya pengaruh debt to equity ratio terhadap return saham.

\section{Pendahuluan}

Pasar modal dapat berfungsi sebagai lembaga perantara (intermediares). Fungsi ini menunjukkan peran penting pasar modal dalam menunjang perekonomian karena pasar modal dapat menghubungkan pihak yang membutuhkan dana dengan pihak yang mempunyai kelebihan dana. Selain itu, pasar modal mendorong terciptanya alokasi dana yang efisien, karena dengan adanya pasar modal maka

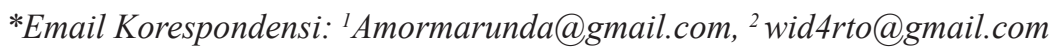


pihak yang kelebihan dana (investor) dapat memilih alternative investasi yang memberikan return yang paling optimal (Tandelilin, 2001). Dalam kaitannya dengan investasi saham, investor memilih saham perusahaan yang layak untuk dipilih berdasarkan kriteria tertentu. Menurut Purnomo (1998), kriteria yang umum digunakan adalah yang aktif diperdagangkan dan fundamentalnya bagus. Investor yang rasional akan mempertimbangkan dua hal yaitu pendapatan yang diharapkan (expected return) dan risiko (risk) yang terkandung dalam alternatif investasi yang dilakukan. Untuk sekuritas atau saham yang memiliki return yang sama, mereka mencari resiko yang terendah. Sedangkan untuk sekuritas atau saham yang memiliki resiko yang sama, mereka memilih return yang tertinggi (Prasetya, 2000). Saham yang banyak diminati oleh investor tersebut akan mengalami kenaikan harga dan return saham, demikian pula sebaliknya.

Kehadiran pasar modal di Indonesia ditandai dengan banyaknya investor yang mulai menanamkan sahamnya dalam industri properti dan realestate. Semakin pesatnyaperkembangan sektor properti dan real estate ini diikuti dengan semakin tingginya permintaan akan kebutuhan papan, sehingga membuat emiten-emiten properti dan real estate membutuhkan dana dari sumber eksternal. Dana dari sumber eksternal dapat diperoleh melalui pasar modal (Husnan, 1998). Analisis fundamental mikro pada dasarnya adalah melakukan analisis historis atas kekuatan keuangan dari suatu perusahaan, dimana proses ini sering juga disebut sebagai analisis perusahaan (company analysis). Data historis mencerminkan keadaan keuangan yang telah lalu yang digunakan sebagai dasar untuk memproyeksikan keadaan keuangan perusahaan dimasa depan. Dalam company analysis para investor (pemodal) akan mempelajari laporan keuangan perusahaan dengan tujuan untuk menganalisis kinerja perusahaan dengan mengetahui kekuatan dan kelemahan perusahaan, mengidentifikasi kecenderungan dan mengevaluasi efisiensi operasional serta memahami sifat dasar dan karakter operasional perusahaan (Ang,1997).

Peningkatan laba oleh perusahaan dapat ditempuh dengan berbagai cara. Salah satunya dengan berinvestasi pada pasar modal. Kegiatan investasi merupakan suatu kegiatan menempatkan dana pada satu atau lebih asset selama periode tertentu dengan harapan dapat memperoleh pendapatan atau peningkatan atas nilai investasi awal(modal) yang bertujuan untuk memaksimalkan hasil (return) yang diharapkan dalam batas risiko yang dapat diterima untuk tiap investor (Jogiyanto, 2000). Namun banyak hal yang harus dipertimbangkan dalam memilih saham yang akan diinvestasikan. Tujuan utama dari aktivitas di pasar modal adalah untuk memperoleh keuntungan (return). Para investor menggunakan berbagai cara untuk memperoleh return yang diharapkan, baik melalui analisis sendiri terhadap perilaku perdagangan saham, maupun dengan memanfaatkan saran yang diberikan oleh para analis pasar modal seperti broker, dealer, manajer investasi dan lain-lain.

Assetgrowthmenunjukkanpertumbuhan per tahun pemakaian aktiva. Asset growth yang tinggi akan berimplikasi pada tingkat resiko yang tinggi pula. Hal ini dapat dijelaskan bahwa pemakaian aktiva yang tinggi akan memberikan tanggungan terhadap pengembalian investasi yang tinggi dan merupakan resiko yang tinggi apabila tidak dapat menutup pengembalian investasi tersebut. Pertumbuhan assets di industri property dan real estate dapat dilihat dari total pendapatan yang diterima. Kondisi ini dapat menyebabkan persaingan dalam sektor properti dan semakin besarnya permintaan akan kebutuhan papan.

Perkembangan industri properti saat ini menunjukkan pertumbuhan yang sangat meyakinkan. Hal ini ditandai dengan maraknya pembangunan perumahan, apartemen, perkantoran dan perhotelan. Disamping itu, perkembangan sektor properti juga dapat dilihat dari menjamurnya real estate di kota-kota besar. Dari perspektif makro ekonomi, industri properti memiliki cakupan usaha yang amat luas sehingga bergairahnya bisnis property pada gilirannya akan berpengaruh terhadap 
pertumbuhan ekonomi dan terbukanya lapangan kerja. Properti juga menjadi indikator penting kesehatan ekonomi sebuah negara. Sebab, industri ini yang pertama memberi sinyal jatuh atau sedang bangunnya perekonomian sebuah negara (Santoso, 2005).

Berdasarkan informasi dari Bursa Efek Indonesia (BEI), Nilai rata-rata return saham berflukfuasi pada angka tertinggi di tahun 2007 sebesar $84.35 \%$, terendah di tahun 2008 ketika terjadinya krisis global sebesar $-36.22 \%$, dan angka naik ditahun 2009 sebesar 18.75\%, kemudian kembali naik sebesar $23.08 \%$ pada tahun 2010. Pada tahun 2011 kembali return saham kembali naik sebesar $40.28 \%$ walau pada tahun ini nilai inflasi naik. Melihat fenomena return saham industri properti dan real estate selama periode 2007 hingga 2011, serta adanya beberapa penelitian terdahulu yang saling bertentangan, dengan demikian memperkuat perlunya diajukan penelitian untuk menganalisis pengaruh debt to equity ratio, pertumbuhan laba, pertumbuhan assets, terhadap return saham (Studi kasus saham industri property dan real estate ang listed di Bursa Efek Indonesia periode 2007 - 2011).

\section{Telaah Teori dan Pengembangan Hipotesis}

\subsection{Signaling Theory}

Signalling theory menekankan kepada pentingnya informasi yang dikeluarkan oleh perusahaan terhadap keputusan investasi pihak di luar perusahaan. Informasi merupakan unsur penting bagi investor dan pelaku bisnis karena informasi pada hakekatnya menyajikan keterangan, catatan atau gambaran baik untuk keadaan masa lalu, saat ini maupun keadaan masa yang akan datang bagi kelangsungan hidup suatu perusahaan dan bagaimana pasaran efeknya. Informasi yang lengkap, relevan, akurat dan tepat waktu sangat diperlukan oleh investor di pasar modal sebagai alat analisis untuk mengambil keputusan investasi.

Menurut Jogiyanto (2000: 392), informasi yang dipublikasikan sebagai suatu pengumuman akan memberikan signal bagi investordalampengambilankeputusaninvestasi. Jika pengumuman tersebut mengandung nilai positif, maka diharapkan pasar akan bereaksi pada waktu pengumuman tersebut diterima oleh pasar. Signaling Theory berkaitan dengan adanya informasi yang asimetris dipasar(Morris, 1987) yang dapat dikurangi bila pihak yang mempunyai lebih banyak informasi memberikan signal kepada pihak yang kekurangan informasi. Pada sebagian besar model signaling tahapan berikut ini terjadi; pada awalnya penjual di pasar diasumsikan memiliki informasi yang lebih tentang produk dibandingkan pembeli. Bila pembeli tidak mempunyai informasi tentang produk tersebut maka pembeli akan berpersepsi bahwa semua produk mempunyai harga rata-rata sama. Penjual yang kualitas produknya diatas rata-rata akan mempunyai peluang untuk rugi karena sebenarnya produknya dapat dijual dengan harga yang lebih tinggi bila pembeli mengetahui tentang kualitasnya sedangkan penjual produk yang berkualitas lebih rendah akan memiliki peluang mendapatkan keuntungan. Karenanya penjual yang mempunyai produk yang berkualitas lebih tinggi sebaiknya mengkomunikasikan kualitas produknya kepada pembeli.Komunikasi ini dilakukan melalui pemberian sinyal (signaling). Agar efektif sinyal ini sebaiknya tidak mudah ditiru oleh penjual produk yang berkualitas lebih rendah.

Bagi perusahaan yang go public pemberian signal kepada investor dapat dilakukan dengan berbagai cara, misalnya pembagian cash dividen dalam jumlah besar akan mengisyaratkan bahwa perusahaan dalam kondisi keuangan yang baik, strategi ini akan sulit ditiru perusahaan yang mempunyai kondisi keuangan kurang baik. Demikian pula informasi perturmbuhan laba, pertumbuhan assets dan rasio debt to equity ration dapat dijadikan signal bahwa perusahaan dalam kondisi keuangan yang baik dan perusahaan berupaya untuk menjaga keberlanjutannya. 


\subsection{Return Saham}

Return Saham adalah tingkat keuntungan yang dinikmati oleh pemodal atas suatu investasi yang dilakukannya. Tanpa ada tingkat keuntungan yang dinikmati dari suatu investasi, tentunya investor tidak akan melakukan investasi. Menururt Ang (1997), setiap investasi baik jangka panjang maupun jangka pendek mempunyai tujuan utama mendapatkan keuntungan yang disebut return baik langsung maupun tidak langsung. Lebih lanjutAng (1997) menyatakan bahwa komponen return terdiri dari dua jenis yaitu current return dan capital gain (keuntungan selisih harga), hal yang sama diungkapkan Hartono (1998) current income merupakan keuntungan yang diperoleh melalui pembayaran yang bersifat periodik seperti bunga deposito, bungan obligasi, dividen, dan sebagainya. Komponen kedua dari return adalah capital gain, yaitu keuntungan yang diterima karena adanya selisih harga antara harga beli dengan harga jual saham yang diperdagangkan di pasar modal dalam hal ini di Indonesia jual beli saham publik di Bursa Efek Jakarta. Dengan adanya jual beli maka akan timbul perubahan nilai harga suatu saham berupa capital gain. Besarnya capital gain dihitung dengan menggunakan analisis return historis yang terjadi pada periode sebelumnya, sehingga dapat dihitung besarnya tingkat kembalian yang diinginkan (expected return).

Expected return merupakan return (kembalian) yang diharapkan oleh investor atas suatu investasi yang akan diterima pada masa yang akan datang. Faktor yang mempengaruhi return suatu investasi meliputi faktor internal maupun faktor eksternal. Faktor Internal perusahaan meliputi kualitas dan reputasi manajemen, strukturpermodalan, strukturutang, tingkat laba yang dicapai dan kondisi-kondisi internal perusahaan yang lain. Faktor Eksternal perusahaan meliputi pengaruh kebijakan moneter dan fiskal, perkembangan sektor industri, faktor ekonomi dan sebagainya (Robert Ang, 1998). Return ekspektasi merupakan return yang diharapkan akan diperoleh dimasa yang akan datang (Jogiyanto Hartono, 1998)

Return Realisasi dihitung dengan formula:

Rit $=\frac{(\text { Pit }- \text { Pi(tt-1) })+\text { Di }}{--------------}$

Keterangan :

Rit $=$ Return saham i pada saat

Pit $=$ Harga saham i pada saat $\mathrm{t}$

$\operatorname{Pi}(\mathrm{tt}-1)=$ Harga Saham $\mathrm{i}$ pada saat $\mathrm{t}-1$

Di $=$ Deviden Saham $\mathrm{i}$

\subsection{Debt to Equity Ratio}

Debt to Equity Rato (DER), yang merupakan kelompok rasio solvabilitas Nilai DER ditujukkan dengan total debts yang dibagi dengan nilai total sareholders equity. Semakin tinggi DER menunjukkan semakin besar total hutang terhadap total ekuitas (Ang, 1997), juga akan menunjukkan semakin besar ketergantungan perusahaan terhadap pihak luar (kreditur) sehingga tingkat resiko perusahaan semakin besar. Hal ini membawa dampak pada menurunnya harga saham di bursa, sehingga return saham akan menurun. Debt to Equity Ratio (DER), yang merupakan kelompok rasio solvabilitas juga menjadi salah satu variabel dalam penelitian ini. Hal tersebut dikuatkan oleh penelitian Liestyowati (2002) mengatakan bahwa DER mempunyai pengaruh negatif terhadap return saham. Akan tetapi penelitian yang dilakukan oleh Natarsyah (2000) mengemukakan bahwa DER berpengaruh signifikan positif terhadap return saham. Berdasarkan hal tersebut maka dapat diambil hipotesis bahwa terdapat pengaruh signifikan negative debt to equity ratio (DER) terhadap return saham.

Ang, 1997). Secara matematis debt to equity ratio (DER) dapat dirumuskan sebagai berikut:

$$
D E R=\frac{\text { Total Hutang }}{\text { Total Ekuitas }}
$$

\subsection{Pertumbuhan Laba}


Menurut Hanafi dan Halim sebagaimana dikutip Angkoso (2006) menyebutkan bahwa pertumbuhan laba dipengaruhi oleh beberapafaktor antara lain:

1. Semakin besar suatu perusahaan, maka ketepatan pertumbuhan laba yang diharapkan semakin tinggi.

2. Umur perusahaan Perusahaan yang baru berdiri kurang memiliki pengalaman dalam meningkatkan laba,sehingga ketepatannya masih rendah.

3. Tingkat leverage Bila perusahaan memiliki tingkat hutang yang tinggi, maka manajer cenderung memanipulasi laba sehingga dapat mengurangi ketepatan partumbuhan laba.

4. Tingkat penjualan Tingkat penjualan di masa lalu yang tinggi, semakin tinggi tingkat penjualan di masa yang akan datang sehingga pertumbuhan laba semakin tinggi.

5. Semakin besar perubahan laba masa lalu, semakin tidak pasti laba yang diperoleh di masa mendatang.

\subsection{Pertumbuhan Aset}

Pertumbuhan aktiva adalah perubahan (peningkatan atau penurunan) total aktiva yang dimiliki oleh perusahaan. Dalam penelitian ini pertumbuhan aktiva dihitung sebagai persentase perubahan aset pada tahun tertentu terhadap tahun sebelumnya. Semakin tinggi pertumbuhan perusahaan maka semakin besar kebutuhan dana untuk pembiayaan ekspansi. Menurut Sartono (2001:248) semakin besar kebutuhan dana, maka semakin besar keinginan perusahaan untuk menahan laba. Jadi, perusahaan yang sedang tumbuh sebaiknya tidak membagikan laba sebagai dividen, melainkan digunakan untuk pembiayaan investasi. Namun apabila laba ditahan tidak cukup untuk memenuhi kebutuhan dana perusahaan, maka perusahaan bersangkutan dapat menggunakan dana tambahan yang berasal dari luar perusahaan dalam bentuk hutang.

Brigham dan Houston (2001:13) juga berpendapat bahwa perusahaan dengan tingkat pertumbuhan aktiva yang cepat harus lebih banyak dana eksternal. Sesuai dengan pecking order theory, apabila pendanaan eksternal dibutuhkan perusahaan cenderung menggunakan pendanaan eksternal berupa hutang dari pada modal sendiri.

\subsection{Penelitian Terdahulu}

Penelitian Restiyani (2006), melakukan penelitian mengenai analisis faktor-faktor fundamental terhadap return saham. Objek penelitian ini adalah perusahaan otomotif dan komponennya. Periode pengamatan yang digunakan dalam penelitian ini pada tahun 2001-2004. Variabel penelitian yang digunakan adalah current ratio (CR), debt to equity ratio (DER), price to book value (PBV), dan total asset turnover (TAT) sebagai variabel independen dan return saham sebagai variabel dependen. Peneliitan ini membuktikan variabel CR, DER, dan PBV secara individual tidak berpengaruh secara signifikan terhadap nilai return saham sedangkan variabel TAT secara individu berpengaruh secara signifikan terhadap return saham. Penelitian ini juga membuktikan bahwa variabel DER, Pertumbuhan Laba dan Pertumbuhan Assets secara bersa-sama berpengaruh secara signifikan terhadap return saham. Penelitian ini menggunakan metode regresi linear.

Penelitian Widyarani (2006), penelitian ini meneliti tentang pengaruh faktor-faktor fundamental dan makroekonomi terhadap nilai return saham. Variabel yang digunakan dalam penelitian ini adalah CR, TAT, net profit margin (NPM), retun on equity (ROE), DER, earning per share (EPS), price earning ratio (PER), dan price to book value (PBV) sebagai variabel independen. Variabel dependen yang digunakan dalam penelitian ini adalah return saham. Sampel penelitian yang digunakan adalah perusahaanperusahaan yang bergerak dalam miscellaneous industries pada periode pengamatan 20022003. Metode yang digunakan dalam penelitian ini adalah regesi berganda. Hasil penelitian menyatakan bahwa CR, TAT, NPM, ROE, EPS, 
PER, PBV tidak berpengaruh secara signifikan terhadap return saham sedangkan variabel DER berpengaruh secara signifikan terhadap return saham.

Penelitian IGK Ulupui (2006), penelitian ini meneliti tentang pengaruh rasiorasio keuangan seperti likuiditas, leverages, aktivitas, dan profitabilitas terhadap return saham. Sampel penelitian adalah perusahaan makanan dan minuman yang terdaftar di BEJ. Metode yang digunakan dalam penelitian ini adalah metode regresi berganda. Variabelvariabel yang digunakan dalam penelitian ini adalah CR, DER, TAT, dan ROA sebagai variabel independen dan return saham sebagai variabel dependen. Hasil penelitian ini membuktikan CR dan ROA berpengaruh positif dan signifikan. DER berpengaruh positif tetapi tidak signifikan. TAT berpengaruh negatif dan tidak signifikan. Secara simultan, semua variabel berpengaruh terhadap return saham secara signifikan.

Penelitian Suharli (2005), meneliti tentang dua faktor fundamental yaitu solvabilitas dan resiko sistematik perusahaan dalam mempengaruhi return saham. Objek penelitian ini adalah perusahaan food \& beverages. Rasio solvabilitas diwakili oleh DER dan resiko sistematik diwakili oleh beta saham. Penelitian ini menggunakan metode regresi berganda. Hasil penelitian ini menyatakan bahwa variabel DER dan beta saham tidak berpengaruh secara signifikan terhadap return saham.

\subsection{Kerangka Pemikiran}

Gambar 1.

\section{Bagan Rerangka Pemikiran}

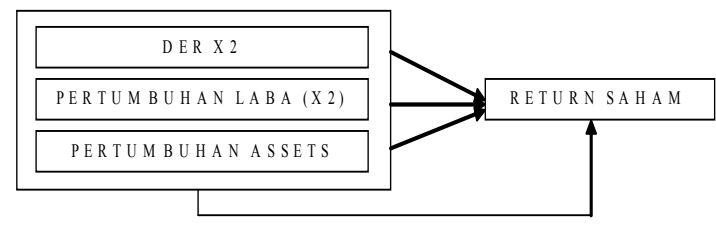

Perumusan Hipotesis :

H1 : DER berpengaruh negatif dan signifikan terhadap return saham.
H2 : Pertumbuhan Laba berpengaruh positif dan signifikan terhadap return saham.

H3 : Pertumbuhan Assets berpengaruh positif dan signifikan terhadap return saham

H4 : Debt to Equity Ratio, Pertumbuhan Laba, Pertumbuhan Asset ssecara bersma-sama berpengaruh signifikan terhadap return saham.

\section{Metode Penelitian}

Tempat penelitian berada di Bursa efek Indonesia di Jakarta dengan cara mengunjungi website http://www.idx.co.id dan dari Indonesia Capital Market Directory (ICMD) pada perusahaan Property dan Real Estate yang telah mempublikasikan laporan keuangan tahunannya. Waktu pengambilan data dalam penelitian ini dilakukan untuk periode 5 tahun yaitu dari tahun 2007 sampai tahun 2011.

Data kuantitatif adalah data yang menunjukan pengukuran yang dinyatakan dengan angka dan penggolongannya dengan interval dan rasio. (Ety Rochaety, 2007:89). Data kuantitatif merupakan data yang berbentuk angka dan dapat mengopersaikan tanda matematika. Jadi angka-angka tersebut dapat dihitung. (I Made Wiratha, 2005:34). Data kuantitatif adalah data yang dinyatakan dalam bentuk angka. (Supranto,2004:62). Data yang digunakan dalam penelitian ini adalah data kuantitatif, yaitu yang dinyatakan dengan angka-angka yang menunjukan besarnya nilai variabel yang diteliti berupa laporan keuangan yang mencakup Debt to Equity Ratio, Pertumbuhan Laba, Pertumbuhan Assets. Data harga saham diambil dari harga penutupan (closing price). Data yang digunakan dalam penelitian ini adalah data sekunder diperoleh dari Bursa Efek Indonesia,

Pupulasi data adalah keseluruhan subjek penelitian, apabila seseorang ingin meneliti semua elemen yang ada dalam wilayah penelitian, maka penelitiannya merupakan penelitian populasi. (Suharsimi, 2010:173)

Populasi dalam penelitian ini adalah semua perusahaan Properti dan Real Estate 
yang go public yang terdaftar di Bursa efek Indonesia (BEI) periode 2007 sampai dengan tahun 2011 sebanyak 10 perusahaan. Dalam penelitian ini metoda pengambilan sampel yang digunakan adalah Purposive Sampling dengan cara menetapkan kriteria-kriteria tertentu diantaranya:

a. Perusahaan yang menjadi sampel adalah seluruh perusahaan property dan real estate yang terdaftar di bursa efek Indonesia dari tahun 2007 sampai dengan tahun 2011.

b. Perusahaan tersebut secara periodik menyajikan laporan keuangan per 31 Desember 2007 - 2011

c. Saham perusahaan tersebut aktif diperdagangkan di BEI selama periode $2007-2011$. regresi linier berganda dengan bantuan program komputer Statistical Package for Social Science (SPSS) versi 17.0. Diantaranya yaitu dengan menggunakan Uji asumsi klasik, uji normalitas, uji Multikolinearitas, uji autokorelasi, heterokedasitas. Sedangkan untuk pengujian hipotesis menggunakan analisis regresi linear berganda. Menurut Ghozali (2009) ketepatan fungsi regresi sampel dalam menaksir nilai aktual dapat diukur dari Goodness of fitnya. Secara statistik $\mathrm{F}$ dan nilai statistik $\mathrm{t}$. Perhitungan statistik disebut signifikan secara statistik apabila nilai uji statistiknya berada dalam daerah kritis (daerah dimana $\mathrm{H} 0$ ditolak). Sebaliknya disebut tidak signifikan bila nilai uji statistiknya berada dalam daerah $\mathrm{H} 0$ diterima.

Tabel 1.

Jumlah Sampel Berdasarkan Kriteria

\begin{tabular}{clc}
\hline No & \multicolumn{1}{c}{ Kriteria Sampel } & Jumlah \\
\hline 1. & $\begin{array}{l}\text { Perusahaan Property dan Real Estate yang terdaftar di BEI berturut-turut mulai dari } \\
\text { tahun 2007 sampai dengan tahun 2011. }\end{array}$ \\
2. & $\begin{array}{l}\text { Perusahaan Property dan Real Estate yang tidak secara berturut-turut mempublikasikan } \\
\text { laporan keuangan mulai dari tahun 2007 sampai dengan tahun 2011. }\end{array}$ & 33 \\
& Jumlah Sampel & 10 \\
\hline
\end{tabular}

Tabel 2

Sampel Penelitian

\begin{tabular}{ccc}
\hline No & Kode Emiten & Nama Perusahaan \\
\hline 1 & BIPP & Bhuwanatala Indah Permai Tbk \\
2 & DART & Duta Anggada Realty Tbk \\
3 & FMII & Fortune Mate Indonesia Tbk \\
4 & JRPT & Jaya Real Property Tbk \\
5 & KIJA & Kawasan Industri Jababeka Tbk \\
6 & KPIG & Kridaperdana Indahgraha Tbk \\
7 & LAMI & Lamicitra Nusantara Tbk \\
8 & LPKR & Lippo Karawaci Tbk \\
9 & MORE & Indonesia Prima Property Tbk \\
10 & PWON & Pakuwon Jati Tbk \\
\hline
\end{tabular}

Metode analisis data dalam penelitian ini, untuk mengetahui pengaruh Debt to Equity Ratio, Pertumbuhan Laba,dan Pertumbuhan Assets terhadap return saham pada perusahaan property dan real estate digunakan analisis
Model empiris yang digunakan adalah sebagai berikut:

$\mathrm{Y}=\mathrm{a}+\mathrm{b}_{1} \mathrm{X}_{1}+\mathrm{b}_{2} \mathrm{X}_{2}+\mathrm{b}_{3} \mathrm{X}_{3}+\mathrm{e}$

Keterangan :

$\mathrm{Y}=$ Return Saham 


$$
\begin{array}{ll}
\mathrm{a} & =\text { Konstanta } \\
\left.\mathrm{b}_{1,2,3}\right) & =\text { Koefisien Regresi } \\
\mathrm{X}_{1} & =\text { DER } \\
\mathrm{X}_{2} & =\text { Pertumbuhan Laba } \\
\mathrm{X}_{3} & =\text { Pertumbuhan Assets } \\
\mathrm{e} & =\text { Error }
\end{array}
$$

Pengujian hipotesis dan analisis data dalam penelitian ini dapat diidentifikasikan variabel-variabel yang akan digunakan dalam model penelitian yaitu:

a. Dependent variabel (Y) atau variabel terikat adalah variabel yang dipengaruhi oleh variabel bebas. Variabel terikat dalam penelitian ini adalah return saham.

b. Independent variabel (X) atau variabel bebas adalah variabel yang mempengaruhi variabel lainnya. Variabel bebas yang digunakan dalam penelitian ini adalah Debt to Equity Ratio $\left(\mathrm{X}_{1}\right)$, Pertumbuhan Laba $\left(\mathrm{X}_{2}\right)$, Pertumbuhan Assets $\left(\mathrm{X}_{3}\right)$.

\section{Hasil Penelitian Dan Pembahasan}

Berdasarkan data-data dalam penelitian ini, maka dilakukan pengujian asumsi klasik yang pada dasarnya untuk melihat apakah datadata dalam penelitian ini dapat digunakan untuk meregresikan antara variabel bebas (DER, Pertumbuhan Laba dan Pertumbuhan Assets) dan variable terikat (Return saham). Dari hasil pengolahan data tersebut kemudian akan dilakukan pembahasan yang lebih mendalam.

Berdasarkan hasil analisis deskriptif statistik variabel return saham diperoleh nilai minimum -78.26, nilai maksimum 455.56, nilai rata-rata (mean) 26.0486 dengan standar deviasi 93.00419. Variabel DER memiliki nilai minimum 0.07 , nilai maksimum 4.04 , nilai rata-rata 1.3570 dengan standar deviasi sebesar 0.98327. Variabel pertumbuhan laba memiliki nilai minimum -250.47 , nilai maksimum 7.18 , nilai rata-rata -5.3144 dengan standar deviasi sebesar 35.51020. Variabel pertumbuhan assets memiliki nilai minimum-21.17, nilai maksimum 734.23, nilai rata-rata sebesar 29.9880 dengan standar deviasi sebesar 105.51698.

Hasil uji multikolinearitas nilai
Tolerance untuk variabel DER sebesar 0.881 dan nilai VIF sebesar 1.135.Variabel pertumbuhan laba diperoleh nilai Tolerance sebesar 0.942 dan nilai VIF sebesar 1.062. Variabel Pertumbuhan Assets diperoleh nilai Tolerance sebesar 0.890 dan nilai VIF sebesar 1.124. Dengan demikian, berdasarkan hasil analisis dengan menggunakan Tolerance dan Variance Inflation Factor (VIF), maka dapat disimpulkan bahwa model penelitian ini tidak terdapat multikolinearitas.

Berdasarkan hasil analisis regresi diperoleh nilai Durbin-Watson (DW) sebesar 2.234, nilai tabel dengan menggunakan nilai signifikan 5\%, jumlah sampel (n) 50 dan jumlah variabel independen $3(k=3)$. Dari tabel DurbinWatson (DW) tersebut berada diantara $\mathrm{dl}$ (batas luar $)=1.4206 ; \mathrm{du}($ batas dalam $)=1.6739 ; 4-\mathrm{du}$ $=2.3261 ; \mathrm{dan} 4-\mathrm{dl}=2.5794$. Dengan demikian dapat disimpulkan bahwa DW-test terletak diantara du dan 4-du menunjukan bahwa Durbin Watson berada didaerah tidak ada autokorelasi. Sehingga data yang digunakan dalam penelitian ini bebas dari autokorelasi.

Hasil uji heteroskedastisitas yang berupa garis plot menunjukan bahwa tidak ada pola yang jelas, serta titik-titik menyebar diatas dan dibawah angka 0 pada sumbu Y, maka keadaan ini dapat disumpulkan tidak terjadi heterokedastisitas. Hasil uji heteroskedastisitas berdasarkan Spearman's rho diperoleh nilai Sig. 2-tailed Unstandardized Residual untuk variabel DER adalah 0.979, variabel pertumbuhan laba 0.549 dan variabel pertumbuhan assets 0.769 , maka dapat disimpulkan bahwa tidak terdapat gejala heteroskedastisitas pada model regresi yang digunakan.

Dengan melihat tampilan grafik histogram berbentuk pola lonceng dapat disimpulkan bahwa grafik histogram memberika pola distribusi yang mendekati normal. Sementara pada grafik normal plot terlihat titiktitik menyebar disekitar garis diagonal. Kedua grafik tersebut menunjukan bahwa model regresi layak dipakai karena memenuhi asumsi normalitas.

Dari hasil analisis regresi diketahui 
$\mathrm{N}$ (50), K (3) dengan df=n-k-1 (46), dapat diketahui bahwa secara bersama-sama variabel independen memiliki pengaruh yang signifikan terhadap variabel dependen. Hal ini dapat dibuktikan dari nilai $\mathrm{F}$ hitung sebesar 29.941 dengan nilai signifikansi sebesar 0,000, sedangkan $\mathrm{F}$ tabel 2,81, sehingga $\mathrm{F}$ hitung $>\mathrm{F}$ tabel $(29.941>2,81)$ dan probabilitasnya jauh lebih kecil dari 0,05 atau 5\%, maka model regesi dapat digunakan untuk memprediksi return saham atau dapat dikatakan bahwa DER, pertumbuhan laba dan pertumbuhan assets secara bersama-sama berpengaruh signifikan terhadap return saham. sebesar 0.660 artinya setiap kenaikan 1 persen dari pertumbuhan assets dan variabel independen lainnya tetap, maka akan menyebabkan kenaikan return saham sebesar 0.660 persen.

Hasil pengujian hipotesis penelitian ini menujukkan hipotesa pertama (H1) DER berpengaruh negatif dan signifikan terhadap return saham ditolak. Hal ini menunjukan bahwa DER berpengaruh negatif dan tidak signifikan terhadap return saham karena di perusahaan property dan real estate di Indonesia para investor merespon positif kondisi pembeli

Tabel 3.

Hasil Uji Regresi

\begin{tabular}{lccc}
\hline \multicolumn{1}{c}{ Variabel } & Koefisien Regresi & t-hitung & Siginifikasi \\
\hline Konstanta & 29.463 & 2,396 & .021 \\
DER (DER) & -14.852 & -1.950 & .057 \\
Pertumbuhan Laba (PLB) & .572 & 2.801 & .007 \\
Pertumbuhan Assets (PA) & .660 & 9.337 & .000 \\
\hline
\end{tabular}

Dengan melihat tabel diatas, dapat disusun persamaan regresi linear berganda sebagai berikut:

Return saham $=$

$$
29.463-14.852 \mathrm{DER}+0.572 \mathrm{PLB}+0.660 \mathrm{PA}
$$

Persamaan regresi diatas mempunyai makna sebagai berikut:

1. Jika DER (X1), PLB (X2), PA (X3) sama dengan nol, maka nilai return saham $(\mathrm{Y})$ sebesar 29.463.

2. Koefisien variabel DER sebesar -14.852 artinya bahwa DER berpengaruh negatif dan signifikan terhadap return saham. Hal ini menunjukan setiap kenaikan 1 persen DER dan variabel independen lainnya tetap, maka akan menyebabkan penurunan return saham sebesar 14.852 persen.

3. Koefisien variabel pertumbuhan laba sebesar 0.572 artinya setiap kenaikan 1 persen dari pertumbuhan laba dan variabel independen lainnya tetap, maka akan menyebabkan kenaikan return saham sebesar 0.572 persen.

4. Koefisien variabel pertumbuhan assets yang antusias dipasar untuk membeli property yang ditawarkan walau bangunan belum jadi atau baru beberapa persen konstruksi dilakukan. Kondisi dimana DER berpengaruh negatif tetapi tidak signifikan bagi para investor untuk berinvestasi. Hipotesis kedua berarti hipotesa kedua (H2) Pertumbuhan laba berpengaruh positif dan signifikan terhadap return saham diterima yang ditunjukkan dengan variabel pertumbuhan laba (X2) dengan t hitung 2,801 signifikansi pada nilai 0,007 dimana lebih kecil dari 0,05 $(0,007<0,05)$. Hipotesis ketiga (H3) pertumbuhan assets berpengaruh positif dan signifikan terhadap return saham diterima yang di buktikan dengan variabel pertumbuhan assets (X3) dengan t hitung 9.337 signifikansi pada nilai 0,000 dimana lebih kecil dari 0,05 $(0,000<0,05)$. Dan Hipotesis keempat $(\mathrm{H} 4)$ diterima karena kandungan informasi DER, pertumbuhan laba dan pertumbuhan assets secara bersama-sama berpengaruh signifikan terhadap return saham.

\section{Simpulan, Keterbatasan dan Implikasi}




\section{Hasil Penelitian}

Hasil analisis yang telah dilakukan pada perusahaan property dan real estate di BEI periode 2007 - 2011 dapat ditarik kesimpulan sebagai berikut :

1. Variabel independen DER, Pertumbuhan Laba dan Pertumbuhan Assets secara simultan (bersama-sama) berpengaruh signifikan terhadap return saham.

2. Secara parsial variabel independen Pertumbuhan laba dan Pertumbuhan assets berpengaruh signifikan terhadap return saham. Perusahaan yang mempublikasikan pertumbuhan laba positif yang tinggi, harga saham akan naik. Begitu sebaliknya, pertumbuhan laba yang buruk akan menurunkan harga saham. Investor seharusnyamengabaikanperusahaandengan catatan pertumbuhan laba yang buruk karena beresiko kerugian terhadap investasi yang ditanamkan atau sulit mendapat pembagian deviden. Pertumbuhan Laba yang meningkat dapat memberikan signal positif kepada investor tentang prospek dan kinerja perusahaan di masa depan, sehingga investor mau membeli saham dengan tujuan agar harga saham mengalami peningkatan. Peningkatan pertumbuhan laba juga merupakan prediksi deviden yang akan dibagikan kepada investor. Semakin tinggi laba bersih akan menyebabkan saham perusahaan semakin diminati investor, sehingga permintaan saham meningkat dan berpengaruh terhadap return saham. Pertumbuhan assets adalah cerminan atas ukuran sebuah perusahaan. Perusahaan sehat mempunyai pertumbuhan assets yang tinggi yang dapat diharapkan memberikan pengembalian investasi sehingga investor akan tertarik untuk membeli saham.

3. Secara parsial variabel DER tidak berpengaruh signifikan terhadap return saham. Kondisi di perusahaan property dan real estate di Indonesia para investor merespon positif kondisi pembeli yang antusias dipasar untuk membeli properti yang ditawarkan walau bangunan belum jadi atau baru beberapa persen konstruksi dilakukan.Kondisi dimana DER berpengaruh negatif tetapi tidak signifikan bagi para investor untuk berinvestasi.

Peneliti menyadari sepenuhnya bahwa penelitian yang telah dilakukan mempunyai keterbatasan-keterbatasan sebagai berikut:

1. Sampel perusahaan yang digunakan hanya perusahaan property dan real eastate yang terdaftar di BEI selama periode 2007 2011 sehingga mempengaruhi akurasi hasil pengujian hipotesis.

2. Variabel independen yang digunakan dalam penelitian ini yang mempengaruhi return saham hanya variabel DER, Pertumbuhan Laba dan pertumbuhan assets sehingga ada kemungkinan bahwa ada faktor-faktor lain yang mempengaruhi return saham namun tidak diteliti dalam penelitian ini.

Berdasarkan keterbatasan diatas, adapun saran yang ditujukan untuk penelitian selanjutnya antara lain :

1. Penelitian ini yang dijadikan sampel hanya perusahaan property dan real esatate, maka diharapkan untuk diperluas cakupan sektor yang diteliti seperti sektor pertambangan, food and beverages, transportasi, farmasi dan sektor agriculture sehingga dapat memberikan hasil yang lebih baik dan akurat.

2. Penelitian ini akan memberikan hasil yang maksimal jika mempertimbangkan untuk menggunakan variabel fundmental perusahaan berupa rasio-rasio keuangan dan variabel eksternal lainnya.

3. Bagi para investor dan calon investor yang ingin berinvestasi saham pada perusahaan property dan real eastate hendaknya mempertimbangkan faktor fundamental, teknikal dan faktor rasional secara umum di Indonesia agar tidak terjadi kesalahan dalam mengambil keputusan untuk berinvestasi

\section{Daftar Pustaka}

Brigham, Eugene, F and Joel. Houstan. 2001, 
Manajemen Keuangan, Terjemahan Tim

Penerbit Erlangga, Edisi Kedelapan, Buku

Dua, Penerbit Erlangga, Jakarta

Ety Rochaety, Ratih,Abdul Madjid. 2007,

Metodologi Penelitian Bisnis. Penerbit

Mitra Wacana Media. Jakarta

Jogiyanto H., dan Triyono. 2000, Hubungan

Kandungan Informasi Arus Kas, Komponen

Arus Kas dan Laba Akuntansi dengan Harga atau Return Saham, Jurnal Riset Akuntansi

Indonesia, Vol 3, no 1, Yogyakarta. Hal. 54-

68

Santoso, Budi. 2005, Prospek Kredit Properti 2005, Economic Review Journal. No. 199

Sartono, Agus. 2001, Manajemen Keuangan International, Edisi Pertama, BPFE, Yogyakarta

Suharsimi Arikunto, 2010, Prosedur Penelitian

Suatu Pendekatan Praktek, PT. Rineka Cipta.

Supranto. 2004, Statistika Pasar Modal Keuangan dan Perbankan. Jakarta : PT. Rineka Cipta

Teguh, Prasetya, 2000, Analisis Rasio

Keuangan dan Nilai Kapitalisasi Pasar sebagai Prediksi Harga Saham di BEJ pada periode Bullish dan Bearish, Simposium Nasional Akuntansi III, IAI - Kompartemen Akuntansi Pendidik, Agustus, pp. 652-695.

Tendelilin, Eduardus. 2001, Analisis Investasi dan Manajemen Portofolio, Yogyakarta : BPFE

Ulupui, IG. K. A. 2007, Analisis Pengaruh Rasio Likuiditas, Leverage, Aktivitas, dan Profitabilitas Terhadap Return Saham (Studi Pada Perusahaan Makanan dan Minuman dengan Kategori Industri Barang Konsumsi di Bursa Efek Jakarta). 